\title{
STAVOVI RODITELJA OSNOVNOŠKOLSKIH UČENIKA GRADA ZAGREBA O UPORABI IKT U NASTAVI NA DALJINU TIJEKOM PANDEMIJE BOLESTI COVID-19
}

\author{
Iva Ivanković ${ }^{1}$, Ivan Igić 2 \\ ${ }^{1}$ Fakultet hrvatskih studija Sveučilišta u Zagrebu, Hrvatska \\ ${ }^{2}$ Osnovna škola Ivana Gundulića, Zagreb, Hrvatska \\ iivankov1@hrstud.hr; igic.iv@gmail.com
}

Primljeno: 16. 9. 2020.

Informacijsko-komunikacijska tehnologija (IKT) uključena je u sve društvene slojeve, a njezina se uloga u odgoju i obrazovanju intenzivirala. Spremnost učitelja kao odgojno-obrazovnih profesionalaca ključan je element za uporabu i implementaciju IKT-a u odgojno-obrazovni proces. Iznenadnom pandemijom bolesti COVID-19 učitelji su stavljeni pred zadatak osmišljavanja i provedbe nastave na daljinu. $S$ ciljem utvrđivanja stavova roditelja o uporabi IKT-a u takvom obliku nastave, tijekom proljeća 2020. godine provedeno je istraživanje na uzorku od 465 sudionika na području Grada Zagreba. Utvrđeno je da najveći broj sudionika postiže prosječne rezultate koji su iznad srednje vrijednosti, što znači da je njihov stav o uporabi IKT-a u provedenoj nastavi na daljinu generalno pozitivan. Pronađene su statistički značajne razlike u pojedinim varijablama stavova o uporabi IKT-a u nastavi na daljinu s obzirom na spol, dob i stupanj naobrazbe sudionika te s obzirom na razred koji djeca sudionika istraživanja polaze. Kvalitativnom analizom pitanja otvorenoga tipa ustanovljena je potreba standardizacije nastave na daljinu u smislu uporabe istih ili sličnih digitalnih alata kako bi se osigurale jednake šanse za sve učenike.

Ključne riječi: IKT, e-učenje, nastava na daljinu, digitalna nastava, nastava za vrijeme pandemije bolesti COVID-19, digitalne kompetencije 


\section{Uvod}

Zatečeni pandemijom bolesti COVID-19 učitelji i nastavnici ${ }^{1}$ našli su se pred zadatkom planiranja i provedbe nastave na daljinu, oblikom nastave s kojim se do sada nisu susretali u tom obimu i koji je doveo $u$ pitanje provedbu i kvalitetu nastavnoga procesa. Upravo je takva specifična situacija potvrdila nužnost cjeloživotnoga obrazovanja učitelja i nastavnika, posebno u smislu razvoja digitalnih kompetencija. Nastava na daljinu prije svega podrazumijeva modificiranje didaktičkog četverokuta koji se odnosi na kontekst nastavnoga procesa u vidu dislokacije nastave iz poznatoga okružja škole u virtualni prostor interneta. Kada je riječ o nastavi na daljinu organiziranoj u vrijeme pandemije bolesti COVID-19 u proljeće 2020. godine, može se reći kako je taj četverokut zamijenjen peterokutom i to u vidu jedne nezaobilazne sastavnice - roditelja. Roditelji su, posebno kada je riječ o djeci mlađe životne dobi, dakle učenicima razredne nastave, preuzeli u tom procesu ulogu medijatora, a ponekad i učitelja. Bez njihove pomoći učenici nižih razreda osnovne škole ne bi mogli samostalno pristupiti digitalnim alatima i virtualnom prostoru online škole. Roditeljima takvo izravno sudjelovanje u nastavi daje legitimitet za kreiranje stavova i mišljenja o online školi.

Sagledavajući sliku suvremenog poučavanja, dakle metoda, oblika i strategija rada u nastavi, jasno je da za razliku od sociocentrički orijentirane nastave u kojoj je naglasak na sadržaju poučavanja i sjedilačko-slušalačko-gledalačkoj nastavi, u pedocentrički orijentiranoj nastavi središnje mjesto zauzima učenik, kao i mediji kojima učenici slobodno manipuliraju te koji služe za realizaciju nastavnoga programa (Bognar, 2005). Učenik ${ }^{2}$ je u suvremenoj nastavi aktivni istraživač. Jedan je od

${ }^{1}$ Prema Državnom pedagoškom standardu osnovnoškolskog sustava odgoja i obrazovanja Republike Hrvatske (2008) učitelj je stručno osposobljena osoba za poučavanje, odgoj i obrazovanje učenika u odgojno-obrazovnoj ustanovi. U članku 100. Zakona o odgoju $i$ obrazovanju u osnovnoj i srednjoj školi (2018) odgojnoobrazovni rad u osnovnoj školi obavljaju učitelji razredne, učitelji predmetne nastave i stručni suradnici, dok odgojnoobrazovni rad u srednjoškolskoj ustanovi obavljaju nastavnici i stručni suradnici. Budući da su se u radu ispitivali stavovi roditelja o osnovnoškolskoj nastavi na daljinu, koristi se pojam 'učitelj' koji se odnosi na osobe i muškog i ženskog spola.

2 U radu se rabi pojam 'učenik', pri čemu se pojam odnosi na djecu i muškog i ženskog spola. 
ključnih zadataka suvremene nastave otkrivanje i usvajanje znanja koja čine cjelovit logičan i dosljedan sustav. Zadaća je suvremene škole uvođenje učenika u cjelovitost svijeta (Tot, 2013). Upravo tu cjelovitost svijeta učenici danas spoznaju putem digitalnih alata, stoga je njima nastava na daljinu pristupačna i zanimljiva. S druge pak strane, materijalni kontekst kao i manjak interpersonalne komunikacije između učenika i učitelja zasigurno mijenjaju dinamiku odgojno-obrazovnog procesa. S obzirom na opću digitalizaciju društva u kojoj mlađi naraštaji odrastaju i time postaju takozvani 'digitalni domoroci', nužna sastavnica učiteljskih kompetencija postaju digitalne kompetencije i njihovo kontinuirano usavršavanje (Prensky, 2001). Školski sustav, kao i svaki drugi sustav, povezan je s općim društvenim promjenama pa je u vidu digitalne transformacije društva evidentna potreba implementacije informacijsko-komunikacijske tehnologije (IKT) u odgojno-obrazovni proces ne samo u smislu razvijanja digitalnih kompetencija ${ }^{3}$ učenika nego i razvoja novih strategija učenja i poučavanja putem digitalnih alata (Jenkins et al., 2007).

Budući da je pandemija bolesti COVID-19 u proljeće 2020. godine izazvala značajne promjene u društvu te da su zbog mjera zaštite brojne društvene djelatnosti, uključujući i opće obvezno i srednjoškolsko obrazovanje u Republici Hrvatskoj promijenile neposredan kontaktni oblik rada u rad na daljinu, važnu ulogu u nastavnom procesu preuzeli su upravo roditelji učenika, prije svega osnovnih, ali i srednjih škola. Roditelji učenika osnovnih škola nužno su se uključili u realizaciju nastave na daljinu i to ne samo u smislu tehničke podrške učenicima nego i izvedbe didaktičko-metodičkih postupaka. Zbog kratkoće vremena organizacije nastave na daljinu, ali i različitih institucionalnih pretpostavki koje se odnose na specifičnosti škola (osposobljenost nastavnog kadra za uporabu digitalne tehnologije, materijalno-tehnološki uvjeti, nastavna sredstva i drugo) te značajne participatorne uloge roditelja u provedbi nastave na daljinu, ovo je istraživanje usmjereno na ispitiva-

${ }^{3}$ Godine 2017. istraživački je centar Europske komisije donio Europski okvir digitalnih kompetencija za obrazovatelje pod nazivom European Framework for the Digital Competence of Educators u kojem je navedeno da se one sastoje od 22 kompetencije podijeljene u šest područja: profesionalni angažman, digitalni izvori i materijali, učenje i poučavanje, praćenje i vrednovanje, osnaživanje učenika i omogućavanje razvoja i usmjeravanje digitalnih kompetencija učenika. 
nje stavova roditelja o uporabi IKT-a u realiziranoj nastavi. Istraživanjem se željelo steći uvid u pozitivne i negativne čimbenike primjene IKT kao i takvoga oblika nastave koji je, s obzirom na dugotrajnost i neizvjesnost pandemije, postao jedan od mogućih oblika formalnog odgoja i obrazovanja.

Razvoj informacijske tehnologije utječe na pojavu novih oblika učenja i poučavanja. Pojam 'informacijska i komunikacijska tehnologija' (IKT) podrazumijeva sva tehnička sredstva koja se upotrebljavaju u svrhu rukovanja informacijama. Čelebić i Rendulić (2011) navode kako se IKT sastoji od informacijske tehnologije, telefona, elektroničkih medija, audiosignala i videosignala te svih funkcija kontrole i nadgledavanja koji se baziraju na mrežnim topologijama. Bakić-Tomić i Dumančić (2012) navode kako primjenom IKT-a od samog početka obrazovanja učenici stječu informatičku pismenost (computer literacy) i informacijsku pismenost (information literacy), odnosno sposobnost korištenja računala i sposobnost nalaženja, procjene i korištenja informacija. Suvremena je djelatnost škole usmjerena na brojne kompetencije, pa tako i na informacijsku pismenost. Jedna od sedam međupredmetnih tema uvedenih 2019. godine u odgojnoobrazovni standard učenika Republike Hrvatske jest i Uporaba informacijske i komunikacijske tehnologije (2019) koja obuhvaća učinkovito, primjereno, pravodobno, odgovorno i stvaralačko služenje informacijskom i komunikacijskom tehnologijom u svim predmetima, područjima i na svim razinama obrazovanja. Budući da se sadržaji i oblici IKT-a neprestano mijenjaju i unapređuju, učitelj kao obrazovni stručnjak treba biti upoznat s prednostima i važnosti IKT-a u nastavi, što zahtijeva kontinuirano profesionalno usavršavanje.

\subsection{E-učenje}

Elektroničko učenje ili e-učenje (e-learning) podrazumijeva izvođenje odgojno-obrazovnog procesa uz pomoć uporabe informacijsko-komunikacijske tehnologije. U kontekstu škole elektroničko se učenje može implementirati u sve nastavne i izvannastavne aktivnosti. Clark i Mayer (2011) definiraju e-učenje kao upute isporučene mrežom na digitalnom uređaju, poput stolnog ili prijenosnog računala ili mobilnog uređaja koji je namijenjen učenju. Spomenuti autori razlikuju dva 
oblika e-učenja: asinkrono i sinkrono. E-učenje je, dakle, krovni termin koji obuhvaća heterogeni skup tehnoloških alata, resursa, aplikacija, procesa i metoda koji se primjenjuju za stvaranje, pohranu, širenje, upravljanje i procjenu znanja (Siozos i Palaigeorgiou, 2008). Nastavno na prethodno navedene činjenice, a zavisno od intenziteta i načina na koji se IKT rabi u nastavnom procesu, razlikuju se četiri oblika obrazovanja s istim ciljem (Smiljčić et al., 2017): klasična nastava ili oblik nastave u kojoj samo učitelj rabi računalo, zatim nastava uz pomoć IKT, hibridna nastava i, konačno, online obrazovanje koje se još naziva i »čisto« eobrazovanje, a odvija se na daljinu isključivo pomoću informacijsko-komunikacijskih tehnologija (Afrić, 2014).

\subsection{Hibridna nastava}

Vuksanović (2009) te Bakić-Tomić i Dumančić (2012) navode kako je hibridna nastava najpogodnija za učenike u osnovnoškolskom obrazovanju zbog obrazovne integracije u učionici, kontakta licem u lice između nastavnika i učenika te obrazovne komunikacije koja se odvija online, a njezin je cilj spojiti klasično obrazovanje i e-učenje. Hibridna je nastava zapravo integracija online obrazovnog okruženja s klasičnom učionicom, to jest kombinacija online metoda rada s klasičnim metodama poučavanja te uporaba raznih medija za učenje na daljinu. Nastavnik, učenik i sustav glavne su komponente hibridnog učenja čime se on razlikuje od online učenja u kojemu nedostaje nastavnik. Također, glavna je pretpostavka ovakvog oblika nastave povezanost učenika sa školom, dok im dostupna tehnologija olakšava i poboljšava proces učenja (Banek, 2014).

\subsection{Sustavi za e-učenje}

Tipičan sustav za e-učenje je web aplikacija kojoj korisnici pristupaju putem web preglednika na svojim računalima. Korisnici mogu pristupati sustavu za e-učenje s bilo kojeg računala dokle god imaju pristup internetu (Smiljčić et al., 2017). Pavlina (2014a, 2014b) navodi osnovne značajke koje bi svaki učinkoviti sustav za e-učenje trebao imati, a sve te značajke imaju ulogu olakšati rad nastavnika i učitelja u obrazovnom procesu kroz integraciju raznorodnih elektroničkih obra- 
zovnih alata: fleksibilnost i sveobuhvatnost sustava, skalabilnost koja se odnosi na mogućnost smanjenja ili povećanja broja sudionika u obrazovnom procesu, poštivanje standarda i interoperabilnost koja omogućava lakše korištenje nastavnih materijala uvezenih iz drugih sustava i lakši izvoz nastavnih materijala iz postojećeg sustava u neke druge sustave, zatim dugovječnost i otvorenost, kvalitetna dokumentacija, isplativost, interaktivnost i intuitivnost sučelja koje korisniku pruža dovoljnu količinu informacija te lakše i brže snalaženje unutar sustava te multimedijska podrška i mogućnost ugradnje dodataka. S obzirom na to da su multimedijski sadržaji jako bitni u procesu e-učenja, korisnicima mora biti omogućeno lako i brzo dodavanje multimedijskih sadržaja. Poznatiji sustavi koji podržavaju eučenje svakako su Moodle i Loomen. U Republici Hrvatskoj koriste se MS Teams, Google ClassRoom, ClassDojo, OneNote Class Notebook, Meduza, Edutorij i brojni drugi.

\section{Cilj, problemi i hipoteze istraživanja}

S obzirom na specifične okolnosti u kojima se našlo hrvatsko društvo, ali i građani drugih europskih i svjetskih zemlja, a koje se odnose na pandemiju bolesti COVID-19 ali i razorni potres koji je pogodio Zagreb 22. ožujka 2020., cilj je ovoga rada ispitati stavove roditelja o uporabi IKT-a u nastavi na daljinu koja se provodila u Zagrebu kontinuirano u razdoblju od 16. ožujka do 11. svibnja 2020. te u smanjenom obimu od 25. svibnja 2020. godine za sve učenike koji su mogli i htjeli pohađati redovitu nastavu osnovnih škola, s obzirom na dob, spol, stupanj naobrazbe, razred koji dijete sudionika istraživanja pohađa te radni status sudionika za vrijeme pandemije. Participacija roditelja u nastavi na daljinu bila je gotovo neizbježna, posebno kada se radi o učenicima razredne nastave i to ne samo u vidu tehničke podrške učenicima nego i u obradi novih nastavnih sadržaja. Sudjelovanje roditelja u nastavi na daljinu bilo je vrlo različito između pojedinih škola, stoga su mišljenja roditelja o provedbi odgojno-obrazovnog procesa i uporabi IKT-a u proljeće 2020. godine izuzetno važna za izradu budućih smjernica u smislu osiguravanja obrazovnih standarda koji omogućuju jednake uvjete svim učenicima neovisno o mogućnostima i kompetencijama roditelja. Budući da je osnovnoškolsko obrazovanje obvezno, nužno je omogućiti jednake obrazovne šanse svim učenicima neovisno 
o materijalnim, ekonomskim i/ili socijalnim čimbenicima ili oblicima nastavnoga procesa, što nije bilo moguće realizirati tijekom epidemiološke mjere lockdowna u proljeće 2020. godine. U skladu s problemom ovoga rada, pretpostavljeno je postojanje razlike u stavovima sudionika istraživanja o uporabi IKT-a u nastavi na daljinu za vrijeme pandemije bolesti COVID-19 s obzirom na spol, dob, stupanj naobrazbe, radni status te razred koji djeca sudionika istraživanja pohađaju. Pretpostavljeno je da će sudionici mlađe životne dobi, višeg stupnja naobrazbe te aktivnog radnog statusa imati pozitivnije stavove. Isto tako, očekivale su se razlike između roditelja učenika polaznika razredne i predmetne nastave $u$ korist učenika predmetne nastave jer oni imaju veća predznanja i iskustva uporabe digitalnih alata te su samostalniji od učenika mlađe životne dobi. Ispitana je i povezanost stupnja naobrazbe i radnoga statusa sudionika s njihovim stavovima prema uporabi IKT-a u nastavi na daljinu. U obzir je uzeta i promjena mjesta boravišta zbog razornog potresa koji je zadesio zagrebačko područje 22. ožujka 2020. godine.

\section{Metode rada}

\subsection{Sudionici istraživanja}

Sudionici istraživanja su roditelji odnosno skrbnici učenika polaznika različitih osnovnih škola u gradu Zagrebu $(\mathrm{N}=465)$ koji su pristali na anonimno sudjelovanje. U istraživanje je bilo uključeno ukupno 465 ispitanika: 400 majki $(\mathrm{N}=400 ; 85,8 \%)$ i 65 očeva $(\mathrm{N}=63 ; 13,5 \%)$. $\mathrm{S}$ obzirom na dob, ispitanici su podijeljeni u četiri skupine: ispitanici mlađi od 30 godina ( $\mathrm{N}=13 ; 2,6 \%$ ), zatim ispitanici u dobi između 31. i 40. godine života $(\mathrm{N}=179 ; 35,8 \%)$, ispitanici između 41. i 50. godine života $(\mathrm{N}=246 ; 49,2 \%)$ te ispitanici stariji od 51 godine $(\mathrm{N}=27 ; 5,4 \%)$. Prema stupnju naobrazbe sudionici su podijeljeni u šest kategorija: nekvalificirani radnik (stupanj osnovnoškolske naobrazbe), srednja stručna sprema (stupanj srednjoškolske naobrazbe), viša stručna sprema (stupanj naobrazbe bacc.), visoka stručna sprema (stupanj naobrazbe magistra struke), magistar znanosti (stupanj naobrazbe magistra znanosti) i doktor znanosti (stupanj naobrazbe doktora znanosti). Najveći je broj sudionika visoke stručne spreme $(\mathrm{N}=173 ; 34,6 \%)$, zatim slijede sudionici srednjoškolske naobrazbe $(\mathrm{N}=154 ; 30,8 \%)$, potom sudi- 
onici više naobrazbe $(\mathrm{N}=60 ; 12 \%)$, slijede sudionici magistri znanosti $(\mathrm{N}=43 ; 8,6 \%)$ pa sudionici doktori znanosti $(\mathrm{N}=29 ; 5,8 \%)$ i konačno sudionici osnovnoškolske naobrazbe $(\mathrm{N}=6 ; 1,2 \%)$. Prema radnome statusu ispitanika u razdoblju od sredine ožujka do kraja svibnja 2020. godine najveći je broj sudionika istraživanja bio trajno zaposlen, no dislociranog radnog mjesta ( $\mathrm{N}=224 ; 44,8 \%), 189$ sudionika je i nakon potresa u Zagrebu 22. ožujka 2020. godine odlazilo na posao $(\mathrm{N}=189$; $37,8 \%$ ), dok se 50 sudionika izjasnilo da je nezaposleno ( $\mathrm{N}=50 ; 10 \%)$. $\mathrm{S}$ obzirom na broj djece u obitelji, najviše je sudionika istraživanja $\mathrm{s}$ dvoje djece u obitelji ( $\mathrm{N}=225 ; 45 \%)$, zatim slijede sudionici s jednim djetetom u obitelji $(\mathrm{N}=113 ; 22,6 \%)$, potom sudionici s troje djece $\mathrm{u}$ obitelji ( $\mathrm{N}=101 ; 20,2 \%)$, zatim s četvero djece u obitelji $(\mathrm{N}=17 ; 3,4$ $\%)$ te konačno sudionici s petero ili više djece u obitelji $(\mathrm{N}=6 ; 1,2 \%)$.

Uz ove sociodemografske podatke upitnikom se pokušalo saznati i koliko je sudionika istraživanja zadržalo mjesto boravišta u svojim domovima, a koliko ih je napustilo svoje domove u vidu privremenog boravka kod prijatelja ili je bilo zbrinuto od strane nadležnih tijela Grada Zagreba. Od ukupnog broja sudionika istraživanja njih se 398 (79,6 \%) izjasnilo da je i nakon potresa ostalo živjeti u svojim domovima; 44 sudionika $(8,8 \%)$ bilo je nakon potresa privremeno zbrinuto kod prijatelja ili članova obitelji, a njih je $5(1 \%)$ bilo zbrinuto od strane nadležnih tijela Grada Zagreba. Iz Zagreba je nakon potresa odselilo 18 sudionika (3,6\%). Na ovo pitanje nije se izjasnilo 35 ispitanika (7\%).

Ispitalo se i mišljenje sudionika o materijalnoj i infrastrukturnoj sigurnosti škola: 79 (17,4 \%) sudionika izjasnilo se da su osnovne škole koje pohađaju njihova djeca nesigurne za nastavak nastavne godine 2019./2020., to jest da pregledom statičara nisu dobile uporabnu dozvolu, dok se 385 sudionika (82,6 \%) izjasnilo da su škole koje pohađaju njihova djeca nakon pregleda statičara zbog potresa uporabljive i sigurne za nastavak nastavne godine. Iako ovo istraživanje nije obuhvatilo reprezentativan uzorak roditelja i skrbnika osnovnoškolske djece u Zagrebu, postotak je učenika koji se nisu mogli vratiti u svoje škole prilično visok. 


\subsection{Mjerni instrument i način provedbe istraživanja}

Za potrebe istraživanja kreiran je online upitnik koji su sudionici dobrovoljno ispunjavali. Upitnik su kreirali autori ovoga rada s ciljem prikupljanja relevantnih podatka iz neposredne odgojno-obrazovne prakse nastave na daljinu koja se prvi put u ovom obimu primijenila u Republici Hrvatskoj s posebnim naglaskom na nastavu učenika polaznika osnovnih škola Grada Zagreba koji su bili uz mjere zaštite zbog pandemije bolesti COVID-19 dodatno opterećeni zbog potresa. Prvi dio upitnika sadrži sociodemografske podatke: dob i spol sudionika istraživanja, stupanj naobrazbe, radni status nakon potresa i za vrijeme pandemije bolesti COVID-19, broj djece u obitelji, razred koji polaze djeca sudionika, uporabljivost zgrada osnovnih škola Grada Zagreba koje pohađaju djeca sudionika istraživanja, mjesto boravišta nakon potresa. Upitnik je također uključio i podatke o nastavnom procesu tijekom pandemije: oblik nastavnog procesa, tehnički uvjeti potrebni učenicima za praćenje nastave na daljinu te medijska sredstva i digitalni alati koje učenici koriste kako bi se realizirala nastava. Drugi dio upitnika čine tvrdnje kojima se nastojalo istražiti stavove sudionika o kvaliteti osmišljenosti nastave na daljinu, razini zanimljivosti primijenjenih digitalnih alata učenicima, korisnosti kvizova u funkciji ponavljanja nastavnih sadržaja, primjenjivosti nekih elemenata nastave na daljinu $\mathrm{u}$ redovitom obliku nastave, to jest u učionicama, te razini uspješnosti komunikacije između učitelja i učenika tijekom nastave na daljinu.

Online upitnik poslan je putem elektroničke pošte na nekoliko stotina adresa ravnatelja, učitelja i nastavnika zagrebačkih škola. Upitnik sadrži pitanja otvorenoga i zatvorenoga tipa. Sudionici istraživanja odgovarali su na tvrdnje na ljestvici Likertovog tipa (od »nimalo se ne slažem $(-2) \ll$ do »u potpunosti se slažem $(+2) \ll)$. Upitnik je primijenjen anonimno i dobrovoljno u razdoblju od 6. do 30. svibnja 2020. godine. Sudionici istraživanja mogli su u svakom trenutku prekinuti sudjelovanje $\mathrm{u}$ istraživanju. Pouzdanost upitnika izražena Cronbachovim alpha koeficijentom na ovom uzroku iznosi $\alpha=0,79$. 


\section{Rezultati i rasprava}

Prema prikupljenim podacima najviše je ispitanih sudionika čija su djeca učenici petog razreda $(\mathrm{N}=86 ; 18,5 \%)$, potom slijede redom učenici drugoga razreda $(\mathrm{N}=73 ; 15,7 \%)$, prvoga razreda $(\mathrm{N}=62 ; 13,3$ $\%)$, trećega razreda $(\mathrm{N}=58 ; 12,5 \%)$, četvrtoga razreda $(\mathrm{N}=56 ; 12,0 \%)$, šestoga razreda $(\mathrm{N}=51 ; 11,0 \%)$, osmoga razreda $(\mathrm{N}=45 ; 9,7 \%)$ te sedmoga razreda $(\mathrm{N}=34 ; 7,3 \%)$. Prema obliku nastave na daljinu najveći broj učenika predmetne nastave izvršava zadatke prema uputama predmetnih učitelja ( $\mathrm{N}=161 ; 32,2 \%)$, dok učenici razredne nastave u najvećoj mjeri prate nastavu na Trećem programu Hrvatske radiotelevizije te rješavaju dodatne zadatke koje im šalje razredna učiteljica $(\mathrm{N}=138$; $27,6 \%$ ). Od digitalnog alata potrebnog za realizaciju nastave na daljinu razredni i predmetni učitelji najviše su se služili virtualnom učionicom kreiranom od strane samoga učitelja ( $\mathrm{N}=44 ; 8,8 \%$ ), a zatim u podjednakoj mjeri slijede virtualna učionica kreirana od strane neke komercijalne kuće $(\mathrm{N}=29 ; 5,8 \%)$ te elektronička pošta za komunikaciju s roditeljima ( $\mathrm{N}=29 ; 5,8 \%$ ). Samo WhatsApp ili Viber grupu za roditelje koristilo je svega trinaest učitelja ( $\mathrm{N}=13 ; 2,6 \%)$, dok je samo virtualnu učionicu kreiranu od strane Ministarstva znanosti i obrazovanja koristilo 5 učitelja $(\mathrm{N}=5 ; 1 \%)$. Najveći broj učitelja koristilo je i kombiniralo ostale vrlo različite digitalne alate $(\mathrm{N}=339 ; 67,8 \%)$.

Rezultati analize drugog dijela upitnika kojim su se ispitivali stavovi roditelja o uporabi IKTa u nastavi na daljinu ukazuju da najveći broj sudionika u svih pet varijabli postiže prosječne rezultate koji su iznad srednje vrijednosti. Naime, ukupan rezultat svih sudionika kreće se između 1 i 5, a najčešći rezultat u svih pet varijabli iznosi $4(\mathrm{D}=4)$. Niži rezultat od vrijednosti 3 označava nepovoljniji, odnosno negativan stav prema nastavi na daljinu, dok viši rezultat označava pozitivan stav. S obzirom na to da su prosječni rezultati u svih pet varijabli iznad brojke 3, može se zaključiti kako su stavovi roditelja o uporabi IKT-a u nastavi na daljinu općenito pozitivni. U Tablici 1 prikazani su prosječni rezultati sudionika u svih pet varijabli skale Stavovi prema uporabi IKT-a u nastavi na daljinu.

Budući da je ovo istraživanje provedeno u specifičnim uvjetima, naime za vrijeme trajanja pandemije bolesti COVID-19 tijekom koje su se provodile posebne mjere zaštite i sigurnosti, to jest takozvani lock- 
down, rezultati ovog istraživanja ne mogu se uspoređivati s rezultatima već postojećih istraživanja kojih je relativno malo. Međutim, zanimljivo je da su slične rezultate o mišljenjima roditelja o nastavi na daljinu i/ili nekim elementima primjene IKT-a u odgojno-obrazovnom procesu dobili i neki drugi autori. Primjerice Karal et al. (2010) kvalitativnom analizom mišljenja roditelja o digitalnim oblicima komunikacije između roditelja i nastavnika utvrdili su kako roditelji generalno imaju pozitivan stav prema takvim oblicima komunikacije (mobilne aplikacije, obrazovne platforme) jer im omogućuju veću fleksibilnost, više slobodnog vremena te nisu ograničene prostorom. Srednji rezultati na varijablama ovoga upitnika »Neki elementi nastave na daljinu korisni su i u redovitoj nastavi« $(\mathrm{M}=3,90)$ te $»$ Komunikacija između učitelja i roditelja (putem digitalnih alata) je uspješna« $(M=3,70)$ također potvrđuju da su sudionici upravo tim elementima nastave na daljinu generalno zadovoljni. Prema rezultatima istraživanja koje su provele službe Ministarstva znanosti i obrazovanja Republike Hrvatske, a kojim su se nastojala utvrditi mišljenja nastavnika i učitelja o provedbi nastave na daljinu, utvrđeno je kako je većina nastavnika i učitelja zadovoljna izvedbom nastave na daljinu, i to čak 95 \% sudionika istraživanja.

Tablica 1. Prosječni rezultati sudionika svih pet varijabli skale Stavovi roditelja o nastavi na daljinu

\begin{tabular}{|l|c|c|}
\hline \multicolumn{1}{|c|}{ Varijabla } & M & SD \\
\hline Nastava na daljinu dobro je osmišljena. & 3,26 & 1,069 \\
\hline Digitalni alati su zanimljivi. & 3,51 & 1,043 \\
\hline Kvizovi u funkciji nastavnih alata su korisni. & 3,88 & 0,976 \\
\hline $\begin{array}{l}\text { Neki elementi nastave na daljinu korisni su i u redovitoj } \\
\text { nastavi. }\end{array}$ & 3,90 & 0,912 \\
\hline $\begin{array}{l}\text { Komunikacija između učitelja i učenika putem } \\
\text { digitalnih alata je uspješna. }\end{array}$ & 3,70 & 1,107 \\
\hline
\end{tabular}

Normalitet distribucije ljestvice ispitan je Kolmogorov-Smirnovljevim testom. S obzirom na činjenicu da se Kolmogorov-Smirnovljev test obično primjenjuje kod velikih uzoraka $(\mathrm{N}>1000)$ te da je izuzetno rigidan, pri određenju normalnosti distribucije podataka provjereni 
su drugi parametri normaliteta distribucije: simetričnost distribucije (skewness) i kurtičnost distribucije (kurtosis). ${ }^{4}$ Kao relevantni kriterij za navedene parametre uzet je kriterij Georgea i Malleryja (2010) prema kojem je distribucija rezultata normalna ako se vrijednosti za simetričnost i spljoštenost distribucije nalaze u rasponu između -2 i +2 . Budući da se rezultati za simetričnost i spljoštenost distribucije rezultata u svih pet varijabli kreću unutar raspona između $-2 \mathrm{i}+2(\mathrm{~S} 1=-$ 0,$45 ; \mathrm{K} 1=-0,39, \mathrm{~S} 2=-0,40 ; \mathrm{K} 2=-0,36, \mathrm{~S} 3=-0,94 ; \mathrm{K} 3=0,82, \mathrm{~S} 4=-0,84$; $\mathrm{K} 4=0,83, \mathrm{~S} 5=-0,68 ; \mathrm{K} 5=-0,19)$, u nastavku istraživanja primijenile su se metode parametrijske statistike.

Kako bi se ispitale razlike u stavovima o uporabi IKT-a u nastavi na daljinu sudionika u ciljanim varijablama (spol, dob, stupanj naobrazbe i radni status), provedeni su postupci bivarijatne analize: izračun značajnosti razlika pomoću Studentovoga testa (Tablica 2) te analize varijance (ANOVA) (Tablica 3) uz post hoc test (Tukey HSD) (Tablica 4). U istraživanju se polazi od pretpostavke da će sudionici mlađe životne dobi (mlađi od 40 godina), višeg stupnja naobrazbe te aktivnog radnog statusa imati pozitivnije stavove o uporabi IKT-a u nastavi na daljinu te da će postojati statistički značajna razlika u spomenutim varijablama.

Tablica 2. Deskriptivni parametri i t-test za varijablu Stavovi prema nastavi na daljinu s obzirom na spol

\begin{tabular}{|c|c|c|c|c|c|c|}
\hline \multicolumn{2}{|c|}{ Varijabla $»$ Spol $«$} & $\mathbf{N}$ & Min & Max & $\mathbf{M}$ & SD \\
\hline \multirow{2}{*}{$\begin{array}{l}\text { Stavovi } \\
\text { prema nastavi } \\
\text { na daljinu }\end{array}$} & Ženski & 400 & 5 & 25 & 18,10 & 3,796 \\
\hline & Muški & 65 & 5 & 25 & 19,17 & 3,356 \\
\hline \multicolumn{7}{|c|}{$\mathrm{df}=459$} \\
\hline \multicolumn{7}{|c|}{$\mathrm{t}=-2,09$} \\
\hline \multicolumn{7}{|c|}{$p(t)=0,08$} \\
\hline
\end{tabular}

${ }^{4}$ Međunarodni je simbol za simetričnost $S$, dok je za spljoštenost $K$. 
Tablica 3. Deskriptivni parametri i analiza varijance (ANOVA) za varijablu Stavovi prema nastavi na daljinu s obzirom na dob, stupanj naobrazbe i radni status

\begin{tabular}{|c|c|c|c|c|c|c|}
\hline \multicolumn{2}{|c|}{ Varijabla $» D o b \ll$} & $\mathbf{N}$ & Min & Max & $\mathbf{M}$ & SD \\
\hline \multirow{4}{*}{$\begin{array}{l}\text { Stavovi } \\
\text { prema nastavi } \\
\text { na daljinu }\end{array}$} & do 30 godina & 13 & 11 & 23 & 17,84 & 4,058 \\
\hline & $31-40$ & 179 & 9 & 25 & 18,27 & 3,915 \\
\hline & $41-50$ & 245 & 5 & 25 & 18,15 & 3,627 \\
\hline & $>50$ & 27 & 13 & 25 & 19,18 & 3,541 \\
\hline \multicolumn{7}{|c|}{$\mathrm{df}=3$} \\
\hline \multicolumn{7}{|c|}{$\mathrm{F}=0,67$} \\
\hline \multicolumn{7}{|c|}{$\mathrm{p}(\mathrm{F})=0,56$} \\
\hline \multicolumn{2}{|c|}{ Varijabla $»$ Stupanj naobrazbe $«$} & $\mathbf{N}$ & Min & Max & $\mathbf{M}$ & SD \\
\hline \multirow{6}{*}{$\begin{array}{l}\text { Stavovi } \\
\text { prema nastavi } \\
\text { na daljinu }\end{array}$} & NKV & 6 & 12 & 22 & 17,16 & 4,167 \\
\hline & SSS & 154 & 10 & 25 & 18,13 & 3,856 \\
\hline & VŠS (bacc.) & 60 & 9 & 25 & 18,95 & 2,976 \\
\hline & VSS & 173 & 5 & 25 & 18,00 & 4,047 \\
\hline & mr. sc. & 43 & 7 & 25 & 18,93 & 3,521 \\
\hline & dr. sc. & 28 & 13 & 24 & 18,07 & 2,720 \\
\hline \multicolumn{7}{|c|}{$\mathrm{df}=5$} \\
\hline \multicolumn{7}{|c|}{$\mathrm{F}=0,99$} \\
\hline \multicolumn{7}{|c|}{$\mathrm{p}(\mathrm{F})=0,42$} \\
\hline \multicolumn{2}{|c|}{ Varijabla $»$ Radni status $«$} & $\mathbf{N}$ & Min & Max & $\mathbf{M}$ & SD \\
\hline \multirow{4}{*}{$\begin{array}{l}\text { Stavovi } \\
\text { prema nastavi } \\
\text { na daljinu }\end{array}$} & Nezaposlen & 50 & 9 & 25 & 18,24 & 3,377 \\
\hline & $\begin{array}{l}\text { Zaposlen - } \\
\text { radim od kuće }\end{array}$ & 223 & 6 & 25 & 18,35 & 3,881 \\
\hline & \begin{tabular}{|l} 
Zaposlen - \\
odlazim na \\
posao
\end{tabular} & 189 & 5 & 25 & 18,16 & 3,676 \\
\hline & U mirovini & 2 & 12 & 16 & 14,00 & 2,828 \\
\hline \multicolumn{7}{|c|}{$\mathrm{df}=3$} \\
\hline \multicolumn{7}{|c|}{$\mathrm{F}=0,94$} \\
\hline \multicolumn{7}{|c|}{$\mathrm{p}(\mathrm{F})=0,41$} \\
\hline
\end{tabular}


Analizom podataka utvrđeno je da ne postoji statistički značajna razlika između stavova sudionika o uporabi IKT-a u nastavi na daljinu i spola $(\mathrm{t}=2,09 ; \mathrm{p}(\mathrm{t})=0,08)$, dobi $(\mathrm{F}=0,67 ; \mathrm{p}(\mathrm{F})=0,56)$, stupnja naobrazbe $(\mathrm{F}=0,99 ; \mathrm{p}(\mathrm{F})=0,42)$ i radnoga statusa $(\mathrm{F}=0,94 ; \mathrm{p}(\mathrm{F})=0,41)$. Ovi se rezultati mogu objasniti činjenicom da je odnos muških i ženskih sudionika u uzorku relativno neravnomjeran. Međutim, analizom pojedinih zavisnih varijabli koje čine varijablu »Stavovi sudionika o uporabi IKT-a u nastavi na daljinu « dobiveni su drugačiji rezultati. Naime, Studentovim t-testom utvrđena je statistički značajna razlika u varijablama »Spol« i »Kvizovi u funkciji nastavnih alata su korisni« $(\mathrm{t}=-2,03$; $\mathrm{p}(\mathrm{t})=0,04)$. Budući da je prosječni rezultat u ovoj varijabli viši kod muškaraca, može se zaključiti kako muški sudionici ovoga istraživanja imaju pozitivniji stav prema kvizovima koji se koriste u nastavi na daljinu i imaju obrazovnu svrhu (žene: $\mathrm{M}=3,84, \mathrm{ST}=0,986$; muškarci: $\mathrm{M}=4,11, \mathrm{ST}=0,907)$. Ovaj je rezultat sukladan rezultatima nekih drugih istraživanja. Primjerice, u istraživanju koje su proveli Bilić i Opić (2013) na uzorku od 325 studenata Učiteljskoga fakulteta Sveučilišta u Zagrebu utvrđena je statistički značajna razlika između spola studenata i učestalosti korištenja interneta za različite sadržaje te je ustanovljeno kako studenti, za razliku od studentica, učestalije koriste internet za kockanje, igrice, aukcije, glazbu i film, odnosno za zabavu i druženje.

Studentovim t-testom utvrđena je statistički značajna razlika u varijablama »Spol« i »Komunikacija s učiteljima je uspješna« $(\mathrm{t}=2,31 ; \mathrm{p}(\mathrm{t})=0,02)$. Prosječni je rezultat $\mathrm{u}$ ovoj varijabli također viši kod muškaraca, stoga se može zaključiti kako muški sudionici smatraju da je razina uspješnosti komunikacije između učitelja i roditelja (žene: $\mathrm{M}=3,65$, ST=1,106; muškarci: $\mathrm{M}=4,00, \mathrm{ST}=1,086)$ tijekom nastave na daljinu bila uspješna u većoj mjeri nego ženske sudionice. Ovaj je podatak prilično zanimljiv s obzirom na to da u malobrojnim istraživanjima slične tematike nisu dobivene razlike u spolu. Primjerice Tezer (2013) u ispitivanju mišljenja roditelja o uporabi interneta osnovnoškolske djece u obrazovne svrhe nije pronašao statistički značajne razlike u stavovima između majki i očeva. Sagledavajući dobivene rezultate može se zaključiti da razlike u nekim varijablama stavova o uporabi IKT-a u nastavi na daljinu proizlaze iz činjenice da muškarci i žene koriste digitalne alate $i$ internet $u$ različite svrhe, stoga se razlikuju i u stavovima o njihovoj uporabi. Naime, prema Eurostatovim podacima iz 2017. go- 
dine (Državni zavod za statistiku) žene više upotrebljavaju internet za posjete društvenim mrežama, a muškarci za čitanje vijesti i neke druge svrhe. Navedeno znači da žene više interpersonalno komuniciraju putem digitalnih alata od muškaraca te stoga imaju i veća očekivanja od takvog oblika komuniciranja. Isto tako, zanimanja koja uključuju primjenu digitalne tehnologije zastupljenija su kod muškaraca nego kod žena pa se može pretpostaviti da muškarci imaju pozitivnije stavove o uporabi digitalne tehnologije u različitim segmentima svakodnevnog života. Primjerice, prema podacima Fakulteta elektrotehnike i računarstva Sveučilišta u Zagrebu od ukupnog broja upisanih studenata 2015. godine studentice čine samo 15 posto. Može se pretpostaviti da je i odnos žena i muškaraca u informatičkom sektoru sličan kada je riječ o vrsti zanimanja.

Analizom varijance testirana je razlika u varijabli »Neki elementi nastave na daljinu korisni su i u redovitoj nastavi« te je utvrđeno da postoji statistički značajna razlika između te varijable $(\mathrm{df}=3 / 463 ; \mathrm{F}=3,19$; $\mathrm{p}(\mathrm{F})=0,02) \mathrm{s}$ obzirom na dob sudionika. Provedenim Tukey HSD post hoc testom utvrdilo se da postoji statistički značajna razlika između sudionika u dobi između 31. i 40. godine i sudionika starijih od 50 godina, kao i između sudionika u dobi između 41. i 50. godine i onih starijih od 50 godina (Tablica 5).

Tablica 4. Tukey HSD post hoc test za varijablu »Neki elementi nastave na daljinu korisni su i u redovitoj nastavi«

\begin{tabular}{|c|c|c|c|c|}
\hline $\begin{array}{l}\text { Varijabla »Neki elementi } \\
\text { nastave na daljinu korisni } \\
\text { su i u redovitoj nastavi« }\end{array}$ & $\begin{array}{c}\text { do } 30 \\
\text { godina } \\
M=3,77\end{array}$ & $\begin{array}{c}\mathbf{3 1 - 4 0} \\
\text { godina } \\
\mathrm{M}=3,84\end{array}$ & $\begin{array}{l}\mathbf{4 1 - 5 0} \\
\text { godina } \\
\mathrm{M}=3,90\end{array}$ & $\begin{array}{c}>50 \\
\text { godina } \\
\mathrm{M}=4,41\end{array}$ \\
\hline do 30 & & 0,99 & 0,95 & 0,15 \\
\hline $31-40$ & & & 0,9 & 0,01 \\
\hline $41-50$ & & & & 0,02 \\
\hline$>50$ & & $\mathbf{0 , 0 1}$ & $\mathbf{0 , 0 2}$ & \\
\hline
\end{tabular}

Budući da je prosječni rezultat u ovoj varijabli najviši kod sudionika starijih od 50 godina ( $\mathrm{M}=19,18 ; \mathrm{ST}=3,541)$, može se zaključiti 
kako stariji sudionici smatraju da su digitalni obrazovni alati i sadržaji korisni i u redovitim oblicima nastave koji se provode u školama. Ovaj se rezultat može tumačiti na način da osobe starije od 50 godina možda nekritički sagledavaju digitalizaciju obrazovanja jer o njoj imaju manje saznanja i iskustva od mlađih osoba. Međutim, ova bi se pretpostavka tek trebala znanstveno istražiti i potvrditi.

Analizom podataka utvrđeno je da ne postoji statistički značajna razlika između stavova sudionika o uporabi IKT-a u nastavi na daljinu i stupnja naobrazbe $(\mathrm{F}=0,99 ; \mathrm{p}(\mathrm{F})=0,42)$, kao ni između stavova o uporabi IKT-a u nastavi na daljinu i radnoga statusa $(\mathrm{F}=0,94 ; \mathrm{p}(\mathrm{F})=0,41)$. Međutim, analizom varijance kojom je testirana razlika u varijablama »Stupanj naobrazbe« i »Komunikacija s učiteljima je uspješna« dobivena je statistički značajna razlika $(\mathrm{df}=5 / 463 ; \mathrm{F}=2,51 ; \mathrm{p}(\mathrm{F})=0,02)$. Provedenim Tukey HSD post hoc testom utvrđeno je postojanje statistički značajne razlike između sudionika visoke stručne spreme i magistra znanosti (Tablica 5).

Tablica 5. Tukey HSD post hoc test za varijablu »Komunikacija s učiteljima je uspješna«

\begin{tabular}{|c|c|c|c|c|c|c|}
\hline $\begin{array}{c}\text { Varijabla } \\
\text { »Komunikacija } \\
\text { u nastavi je } \\
\text { uspješna« } \\
\end{array}$ & $\sum_{\Sigma}^{\infty}$ & 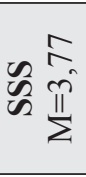 & 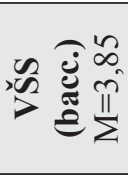 & 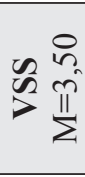 & 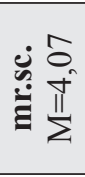 & 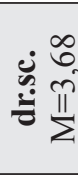 \\
\hline NKV & & 1,00 & 1,00 & 0,97 & 0,99 & 1,00 \\
\hline SSS & & & 0,99 & 0,23 & 0,59 & 0,99 \\
\hline VŠS (bacc.) & & & & 0,26 & 0,91 & 0,98 \\
\hline VSS & & & & & 0,02 & 0,96 \\
\hline mr. sc. & & & & 0,02 & & 0,68 \\
\hline dr. sc. & & & & & & \\
\hline
\end{tabular}

Rezultat se može tumačiti činjenicom da je u cijelom uzorku sudionika relativno mali broj onih koji imaju viši stupanj naobrazbe od magisterija znanosti, kao i pretpostavkom da povećanjem stupnja naobrazbe raste i kritičko promišljanje o komunikaciji roditelja i učitelja u smislu da osobe s višim stupnjem naobrazbe možda više suosjećaju s težinom 
zadatka koji je stavljen pred učitelje tijekom nastave na daljinu - organizacije odgojno-obrazovnog procesa. Prema srednjim vrijednostima u navedenoj varijabli najpozitivniji stav prema uspješnosti komunikacije između roditelja i učitelja imaju sudionici sa završenim magisterijem znanosti ( $M=4,07$; $\mathrm{ST}=0,909)$, dakle visokim stupanjem naobrazbe.

Primjenom analize varijance (ANOVA) utvrđena je statistički značajna razlika između roditelja učenika s obzirom na razred koji učenici polaze $(\mathrm{df}=7 / 463 ; \mathrm{F}=3,03 ; \mathrm{p}(\mathrm{F})=0,00)$ te je Tukey HSD post hoc testom utvrđena razlika između roditelja učenika polaznika petih i trećih razreda (Tablica 6).

Tablica 6. Tukey HSD post hoc test za varijablu »Stavovi o uporabi IKT-a u nastavi na daljinu « s obzirom na razred koji učenici polaze

\begin{tabular}{|c|c|c|c|c|c|c|c|c|}
\hline $\begin{array}{c}\text { Varijabla } \\
\text { »Stavovi } \\
\text { o uporabi } \\
\text { IKT-a u } \\
\text { nastavi na } \\
\text { daljinu« }\end{array}$ & 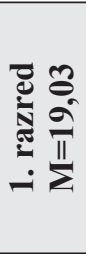 & 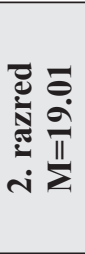 & 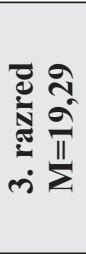 & 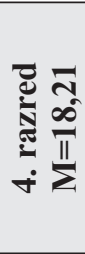 & 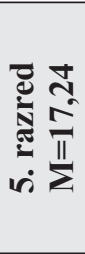 & 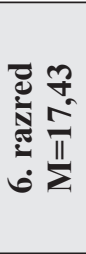 & 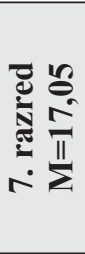 & 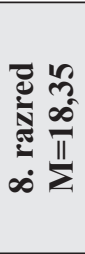 \\
\hline 1. razred & & 1,00 & 1,00 & 0,93 & 0,72 & 0,29 & 0,19 & 0,98 \\
\hline 2. razred & & & 1,00 & 0,92 & 0,54 & 0,26 & 0,17 & 0,98 \\
\hline 3. razred & & & & 0,77 & 0,02 & 0,14 & 0,09 & 0,90 \\
\hline 4. razred & & & & & 0,79 & 0,95 & 0,83 & 1,00 \\
\hline 5. razred & & & 0,02 & & & 1,00 & 1,00 & 0,72 \\
\hline 6. razred & & & & & & & 1,00 & 0,92 \\
\hline 7. razred & & & & & & & & 0,77 \\
\hline 8. razred & & & & & & & & \\
\hline
\end{tabular}

S obzirom na to da su srednje vrijednosti u navedenoj varijabli više kod roditelja učenika trećih razreda $(\mathrm{M}=19,29 ; \mathrm{ST}=3,387) \mathrm{u}$ odnosu na roditelje učenika petih razreda $(M=17,24$; $\mathrm{ST}=3,837)$ može se zaključiti kako roditelji učenika polaznika trećih razreda osnovnih škola imaju pozitivniji stav o uporabi IKT-a u nastavi na daljinu od roditelja učenika petih razreda. Ovaj se odnos u stavovima roditelja učenika razredne i predmetne nastave može tumačiti na nekoliko načina. Prije 
svega, učenici predmetne nastave starosno su zreliji i samostalniji u primjeni digitalnih alata te je stoga potrebna manja uključenost roditelja u realizaciju njihove nastave na daljinu, što posljedično utječe na manjak uvida u sam proces nastave na daljinu. S druge strane, učenicima razredne nastave koji su manje samostalni u uporabi digitalnih alata nužna je pomoć odraslih. Nadalje, veliki broj učenika razredne nastave pratio je nastavu na Trećem programu Hrvatske radiotelevizije te rješavao dodatne zadatke koje im je slala razredna učiteljica $(\mathrm{N}=138 ; 27,6$ \%) pa nisu koristili IKT u tolikoj mjeri kao učenici predmetne nastave. Isto tako, među učenicima predmetne nastave postoji veći diverzitet $\mathrm{u}$ uporabi digitalnih alata i oblika rada u nastavi na daljinu u odnosu na učenike razredne nastave što je možda utjecalo na različitost stavova roditelja o uporabi IKT-a u nastavi na daljinu. I konačno, zanimljivo je da se razlika u stavovima o uporabi IKT-a u nastavi na daljinu pokazala upravo između roditelja učenika trećeg i petog razreda. To se može tumačiti činjenicom da je nastava u petom razredu, kao i u predmetnoj nastavi općenito, strukturalno i organizacijski drugačije koncipirana od razredne nastave koja zahtijeva veći angažman učenika te njihovu prilagodbu na dinamiku odgojno-obrazovnog procesa, što je pak posebno osjetljivo za učenike polaznike petoga razreda i ujedno dodatno otežano u nastavi na daljinu.

Povezanost između stupnja naobrazbe sudionika i varijable »Neki elementi nastave na daljinu korisni su i u redovitoj nastavi« provjerena je izračunom Pearsonovog koeficijenta korelacije te je utvrđeno da postoji pozitivna povezanost između njih (rp $(465)=0,303 ; \mathrm{p}(\mathrm{r})=0,02)$. Ovaj rezultat potvrđuje pretpostavku da s većim stupnjem naobrazbe raste i pozitivan stav sudionika prema korisnosti nekih elemenata nastave na daljinu u redovitoj formalnoj nastavi. Rezultat se može objasniti pretpostavkom da roditelji višeg stupnja obrazovanja češće koriste elektroničke medije u svakodnevnom životu te imaju višu razinu digitalne pismenosti od roditelja nižeg stupnja obrazovanja koji ih zbog prirode posla rjeđe koriste. Sličan rezultat dobili su Pregrad et al. (2010) u istraživanju iskustva i stavova djece, roditelja i učitelja prema elektroničkim medijima. Nepostojanje statistički značajne korelacije između ostalih varijabli stavova prema nastavi na daljinu i stupnja naobrazbe može se objasniti relativno malim uzorkom i neravnomjernom raspodjelom sudionika različitoga stupnja naobrazbe. Izračun Pearsonovog koefici- 
jenta korelacije između varijabli »Mjesto boravišta« $\mathrm{i} »$ Stavovi prema nastavi na daljinu « nije se pokazao statistički značajnim (rp (465)=$0,027 ; \mathrm{p}(\mathrm{r})=0,55)$.

Upitnik je osim tvrdnji postavljenih u obliku Likertove skale od pet stupnjeva sadržavao i prostor predviđen za slobodne komentare sudionika koji su kategorizirani i kvalitativno obrađeni. Sudionicima istraživanja omogućeno je da slobodno komentiraju i iznesu svoja mišljenja i/ili prijedloge unapređenja odgojno-obrazovnog procesa u obliku nastave na daljinu. Komentari ispitanika o uporabi IKT-a u nastavi na daljinu uglavnom su pozitivni. Od ukupnog broja ispitanika $(\mathrm{N}=465)$, slobodni je komentar dao 121 ispitanik $(\mathrm{N}=121)$. Iako je kvalitativna analiza sadržaja istraživačka metoda u kojoj subjektivne interpretacije tekstualnog sadržaja prolaze kroz usustavljen klasifikacijski proces kodiranja i identificiranja tema ili obrazaca (Hsieh; Shannon, 2005), njome se može dobiti uvid u stvarna mišljenja pojedinaca. Iskazi sudionika transkribirani su na način da su se sveli na srodne riječi ili ideje koje su međusobno povezane. Potom je određena frekvencija odgovora istoga koda. Tom je metodom dobiven rezultat koji potvrđuje rezultate dobivene ranije navedenom statističkom obradom podataka. Općenit je stav sudionika da je nastava na daljinu, kao i primjena IKT-a, uspješno provedena, međutim potrebno ju je standardizirati kako bi se osigurale jednake šanse za sve učenike. Isto tako, potrebno je omogućiti slične ili jednake uvjete rada (potrebna informatička oprema dostupna svima) te uvesti jedinstveni komunikacijski alat. Većina sudionika smatra kako su upravo učitelji nositelji kvalitete nastave na daljinu, što je vidljivo iz mnogih iskaza poput ovoga: »Zahvaljujući isključivo trudu, znanju, zalaganju, umijeću i nadasve volji naše učiteljice koja je u ovim okolnostima izvukla maksimum, ova nastava na daljinu ima smisla«. Sudionici koji su putem izjava iskazali negativan stav prema uporabi IKT-a u nastavi na daljinu zahtijevaju nastavu koja će unatoč digitalizaciji omogućiti veći socijalni kontakt odnosno integraciju digitalnih obrazovnih alata (videokonferencija i sl.) i osobnog kontakta. Shodno tome, može se zaključiti da niti jedna informatička tehnologija ne može zamijeniti živu riječ učitelja u neponovljivom trenutku razrednog ozračja u kojemu učenici zajedno napreduju u znanju i usvajanju vještina, sposobnosti i navika. Direktna i neposredna komunikacija te vođeni razgovor 
učitelja i učenika i dalje su, iako najstariji, najsnažniji čimbenik svakog oblika nastave.

\section{Zaključak}

Rezultatima istraživanja utvrđeno je da sudionici, roditelji osnovnoškolske djece u gradu Zagrebu, imaju pozitivan stav o uporabi IKT-a $\mathrm{u}$ nastavi na daljinu koja se provodila tijekom pandemije bolesti COVID-19 u proljeće školske godine 2019./2020. Roditelji su najzadovoljniji spremnošću i snalažljivošću učitelja za uporabu različitih digitalnih alata, što je utvrđeno kvalitativnom analizom njihovih slobodnih izjava, a upravo taj podatak potvrđuje nužnost cjeloživotnog obrazovanja i osposobljavanja učitelja i nastavnika za uporabu digitalne tehnologije. U istraživanju se pošlo od pretpostavke da će sudionici mlađe životne dobi (mlađi od 40 godina), višeg stupnja naobrazbe (visoka stručna sprema) te aktivnog radnog statusa imati pozitivnije stavove o uporabi IKT-a u nastavi na daljinu od nezaposlenih sudionika, sudionika starije životne dobi i nižeg stupnja naobrazbe te da će postojati statistički značajna razlika u spomenutim varijablama. Premda generalno nije potvrđena statistički značajna razlika između sudionika prema spomenutim varijablama, analizom pojedinih varijabli ipak su dobivene statistički značajne razlike. Pokazalo se da u odnosu na sudionice istraživanja sudionici imaju pozitivniji stav prema obrazovnim kvizovima koji se koriste u nastavi na daljinu, kao i pozitivniji stav prema uspješnosti komunikacije između učitelja i roditelja. Zbog malobrojnosti sličnih istraživanja ovi se podaci ne mogu uspoređivati, međutim mogu poslužiti kao putokaz kada je riječ o kreiraju budućih smjernica nastave na daljinu i primjene digitalnih kvizova. Naime, poznato je da muškarci i žene koriste internet i digitalne alate $u$ različite svrhe, pri čemu ih muškarci više koriste za zabavu i razbibrigu, a žene za komuniciranje, stoga se i očekivanja od uporabe spomenutih alata u obrazovne svrhe razlikuju s obzirom na spol sudionika.

Isto tako, pronađena je statistički značajna razlika između dobi roditelja i njihovih mišljenja o korisnosti nekih elemenata nastave na daljinu u redovitoj kontaktnoj nastavi. Razlika je utvrđena između sudionika u dobi između 31. i 40. godine života te sudionika starijih od 50 godina, kao i između sudionika u dobi između 41. i 50. godine života i 
onih starijih od 50 godina. Ovaj rezultat može se objasniti na način da osobe starije od 50 godina imaju manje iskustva s digitalnim medijima i sadržajima od mlađih osoba, što utječe na razinu kritičnosti prema njihovoj uporabi u svakodnevnom životu. Statistički značajna razlika pronađena je između sudionika i njihovih mišljenja o razini uspješnosti komunikacije s učiteljima s obzirom na stupanj naobrazbe. Naime, utvrdila se razlika između sudionika visoke stručne spreme i magistra znanosti, s time da pozitivnije stavove imaju upravo magistri znanosti. Ne iznenađuje činjenica da se pokazala razlika u stavovima o uporabi IKT-a u nastavi na daljinu između roditelja učenika razredne i predmetne nastave. Naime, utvrđena je razlika između roditelja učenika polaznika trećih i petih razreda. Pokazalo se da roditelji učenika polaznika trećih razreda osnovnih škola imaju pozitivniji stav o uporabi IKT-a u nastavi na daljinu od roditelja učenika petih razreda. Prijelaz iz razredne nastave u predmetnu nastavu osjetljiv je za učenike i zahtjevan čak i u standardnim redovitim okolnostima, odnosno neposrednoj nastavi u školama, tako da dobiven rezultat nije neočekivan. Budući da je utvrđena i pozitivna povezanost između stupnja naobrazbe sudionika i njihovih mišljenja o korisnosti nekih elemenata nastave na daljinu, može se pretpostaviti da je stupanj naobrazbe sudionika važan čimbenik koji ima ulogu u kreiranju mišljenja o nastavi na daljinu. S obzirom na to da nije pronađena povezanost između sudionika koji su morali napustiti svoje domove zbog potresa 22. ožujka 2020. i onih koji to nisu morali te njihovih stavova o uporabi IKT-a u nastavi na daljinu, može se zaključiti da mjesto boravka nije ključan čimbenik pri kreiranju mišljenja o uporabi IKT-a u nastavi na daljinu.

Iako ovo istraživanje ima brojna ograničenja koja se ponajviše odnose na veličinu uzorka i velike razlike u njegovoj strukturi (dob i spol), a koje su pak rezultat ograničenog vremena za provedbu istraživanja, rezultati upućuju na činjenicu da su stavovi ispitanih roditelja o uporabi IKT-a u nastavi na daljinu pozitivni unatoč vrlo nepovoljnoj i teškoj društvenoj situaciji zbog pandemije bolesti COVID-19, izolacije djece i roditelja na određeno vrijeme od redovitih kontakata i aktivnosti te premještanja odgojno-obrazovnog procesa u digitalni medij. Rezultat je to velikim dijelom spremnosti učitelja na brzu prilagodbu, koja je pak posljedica njihovih digitalnih kompetencija. Kvalitativnom analizom slobodnih izjava sudionika ustanovljeno je da najveće zamjerke prove- 
dene nastave na daljinu idu u smjeru premale uporabe interaktivnoga sadržaja tijekom nastave, odnosno manjak interakcije između učitelja i učenika. Naglašena je neophodnost ostvarivanja kontakta između učenika i učitelja te njihova neizostavnost kada se radi o metodici poučavanja pojedinih predmeta. Rezultati istraživanja potvrđuju tezu da je interpersonalna komunikacija između učitelja i učenika nezamjenjiva, stoga ju je nužno u nastavi na daljinu i primjeni IKT-a promicati što je više moguće, poštujući pritom prava i jednake šanse za sve učenike.

\section{Literatura}

Afrić, Vjekoslav (2014), »Tehnologije e-obrazovanja i njihov društveni utjecaj«, u: Lasić Lazić, Jadranka (ur.), Informacijska tehnologija u obrazovanju, Zagreb: Zavod za informacijske studije, str. 5-25.

Bakić-Tomić, Ljubica; Dumančić, Mario (2012), »Informacijsko-komunikacijske tehnologije u obrazovanju«, u: Šimović, Vladimir (ur.), Odabrana poglavlja iz metodike nastave informatike, Zagreb: Učiteljski fakultet, str. 7-9.

Banek Zorica, Mihaela (2014), »E-učenje temeljeno na objektima učenja«, u: Lasić-Lazić, Jadranka (ur.), Informacijska tehnologija u obrazovanju, Zagreb: Zavod za informacijske studije, str. 33-59.

Bilić, Vesna; Opić Siniša (2013), »Neki korelati korištenja interneta među studentima«, u: Hrvatić, Neven; Klapan, Anita (ur.), Pedagogija i kultura, Zagreb: Hrvatsko pedagogijsko društvo, str. 90-100.

Bognar, Ladislav (2005), »Teorijski pristupi i terminološka pitanja «, u: Bognar, Ladislav; Matijević, Milan (ur.), Didaktika, Zagreb: Školska knjiga, str. 13-34.

Clark, Ruth Colvin; Mayer, Richard (2011), »e-Learning and the Science of Instruction: Proven Guidelines for Consumers and Designers of Multimedia Learning«, John Wiley \& Sons, Inc. Dostupno na: https://www.public.navy.mil/netc/ntt/pdfs/e-Learning.pdf [11. 9. 2020.]. doi: https://doi. org/10.1002/9781118255971

Čelebić, Gordana; Rendulić, Dario Ilija (2011), ITdesk.info - projekt računalne e-edukacije sa slobodnim pristupom - Priručnik za digitalnu pismenost: osnovni pojmovi informacijske i komunikacijske tehnologije, Zagreb: Odrazi.

European Framework for the Digital Competence of Educators: DigCompEdu (2017), The European Commission's science and knowledge service- European Commission, Dostupno na: https://ec.europa.eu/jrc/en/publication/ eur-scientific-and-technical-research-reports/european-framework-digital-competence-educators-digcompedu [10. 9. 2020.].

George, Darren; Mallery, Paul (2010), »SPSS for Windows step by step: A simple guide and reference 17.0 Update. 10th edition «, Pearson: Boston, Dostupno na: https://wps.ablongman.com/wps/media/objects/385/394732/george4answers.pdf [9. 9. 2020.]. 
Hsieh, Hsiu-Fang; Shannon, Sarah E. (2005), »Three approaches to qualitative content analysis«, Qualitative Health Research, 15(9), str. 1277-1288. doi: https://doi.org/10.1177/1049732305276687

Jenkins, Henry; Clinton, Katie; Purushotma, Ravi; Robison, Alice J.; Weigel, Margaret (2007), »Confronting the challenges of participatory culture: Media education for the 21 st century«, Chicago: The MacArthur Foundation. Dostupno na: https://www.macfound.org/media/article pdfs/JENKINS WHITE PAPER.PDF [2. 9. 2020.].

Karal, Hasan; Ozlu, Aysenur; Kokoc, Mehmet (2010), »Teacher's and parent's opinions on the applicability of online «, Procedia Social and Behavioral Sciences, 9(1), str. 788-794. doi: https://doi.org/10.1016/j.sbspro.2010.12.235

[MZO] Ministarstvo znanosti i obrazovanja (2019), Smjernice za vrednovanje procesa $i$ ostvarenosti odgojno-obrazovnih ishoda u osnovnoškolskome $i$ srednjoškolskome odgoju i obrazovanju, Zagreb: Ministarstvo znanosti i obrazovanja Republike Hrvatske. Dostupno na: https://mzo.gov.hr/UserDocsImages/dokumenti/PristupInformacijama/eSavjetovanja-2019/Smjernice $\% 20$ za\%20vrednovanje \%20procesa\%20i\%20ostvarenosti\%20odgojno-obrazovnih\%20ishoda\%20-\%20eSavjetovanje\%204-12-2019.pdf [8. 8. 2020.].

[MZO] Ministarstvo znanosti, obrazovanja i sporta Republike Hrvatske (2019), Odluka o donošenju kurikuluma za međupredmetnu temu Uporaba informacijske i komunikacijske tehnologije za osnovne i srednje škole u Republici Hrvatskoj, Zagreb: Ministarstvo znanosti i obrazovanja Republike Hrvatske. Dostupno na: https://narodne-novine.nn.hr/clanci/sluzbeni/2019 $01 \quad 7 \quad 150$. html [16. 8. 2020.].

[MZOS] Ministarstvo znanosti, obrazovanja i sporta Republike Hrvatske (2011), Nacionalni okvirni kurikulum za predškolski odgoj te opće obvezno i srednjoškolsko obrazovanje, Zagreb: Ministarstvo znanosti, obrazovanja i sporta Republike Hrvatske.

[NN] Narodne novine (2008), Državni pedagoški standard osnovnoškolskog sustava odgoja i obrazovanja Republike Hrvatske, 63/2008 (13. 9. 2020.).

[NN] Narodne novine (2018), Zakon o odgoju i obrazovanju u osnovnoj i srednjoj školi, 68/18 (16. 8. 2020.)

Pavlina, Krešimir (2014a), »Interoperabilnost sustava za elektroničko učenje«, u: Lasić-Lazić, Jadranka (ur.), Informacijska tehnologija u obrazovanju, Zagreb: Zavod za informacijske studije, str. 77-86.

Pavlina, Krešimir (2014b), »Osnovne odlike sustava za elektroničko učenje«, u: Lasić-Lazić, Jadranka (ur.), Informacijska tehnologija u obrazovanju, Zagreb: Zavod za informacijske studije, str. 25-32.

Pregrad, Jasenka; Tomić Latinac, Martina; Mikulić, Marija; Šeparović, Nikolina (2010), Iskustva i stavovi djece, roditelja i učitelja prema elektroničkim medijima, Zagreb: Ured UNICEF-a za Hrvatsku.

Prensky, Marc (2001), »Digital natives, digital immigrants «, On the Horizon, 9(5), str. 1-6. doi: https://doi.org/10.1108/10748120110424816 
Siozos, Panagiotis D.; Palaigeorgiou, George E. (2008), »Educational technologies and the emergence of e-learning 2.0«, u: Politis, Dionysios (ur.), E-learning methodologies and computer applications in archaeology, London: Information Science Reference, str. 1-17. doi: https://doi.org/10.4018/978-1-59904759-1.ch001

Smiljčić, Ivana; Livaja, Ivan; Acalin, Jerko (2017), »ICT u obrazovanju«, Zbornik radova Veleučilišta u Šibeniku, 3-4(2017), str. 157-170.

Stankov, Slavomir (2009), »E-učenje« (verzija 2.0), slavomirstankov.com. Dostupno na: http://slavomirstankov.com/wordpress/wp-content/uploads/2014/07/ Dio_A.pdf [13. 8. 2020.].

Tot, Daria (2013), Kultura samovrednovanja škole i učitelja, Zagreb: Učiteljski fakultet Sveučilišta u Zagrebu.

Vuksanović, Irena (2009), »Mogućnosti za e-učenje u hrvatskom obrazovnom sustavu«, Napredak: časopis za pedagogijsku teoriju i praksu, 150(3-4), str. 451-466.

\title{
ATTITUDES OF PARENTS OF PRIMARY SCHOOL STUDENTS OF THE CITY OF ZAGREB ON THE USE OF ICT IN DISTANCE LEARNING DURING THE COVID-19 PANDEMIC
}

\author{
Iva Ivanković, Ivan Igić
}

Information and communication technology (ICT) is included in all social strata, and its role in upbringing has intensified. The readiness of teachers as educational professionals is a crucial element for the use and implementation of ICT in the educational process. With the sudden COVID-19 pandemic, teachers were faced with designing and implementing distance learning. This research aimed to determine parents' attitudes on using information and communication technology in distance learning during the COVID-19 pandemic; a survey was conducted on 465 participants. It was found that the largest number of research participants achieve average results that are above the mean value, which means that their attitude about distance learning is generally favorable. Statistically significant differences in the use of ICT were found in individual variables of attitudes towards distance learning concerning gender, age, level of education of participants, and the class attended by the participants' children. Qualitative analysis of open-ended questions identified the need to standardize distance learning using the same or similar digital tools to ensure equal opportunities for all students.

Keywords: ICT, e-learning, distance learning, digital teaching, teaching during the COVID-19 pandemic, digital competences 